\title{
Correction to: Impact of resettlement scheme on vegetation cover and its implications on conservation in Chewaka district of Ethiopia
}

Alemayehu Abera $^{1 *} \mathbb{C}$, Teshome Yirgu ${ }^{2}$ and Abera Uncha ${ }^{2}$

\section{Correction to: Environ Syst Res (2020) 9:2} https://doi.org/10.1186/s40068-020-00164-7

Unfortunately, in the original version of this article (Abera et al. 2020) figure 5 was repeated in Fig. 4.

The corrected Fig. 4 is given below. The original article has been corrected.

1 Department of Geography and Environmental Studies, Mettu University,

Full list of author information is available at the end of the article in this article are included in the article's Creative Commons licence, unless indicated otherwise in a credit line to the material. If material is not included in the article's Creative Commons licence and your intended use is not permitted by statutory regulation or exceeds the permitted use, you will need to obtain permission directly from the copyright holder. To view a copy of this licence, visit http://creativeco mmons.org/licenses/by/4.0/. 


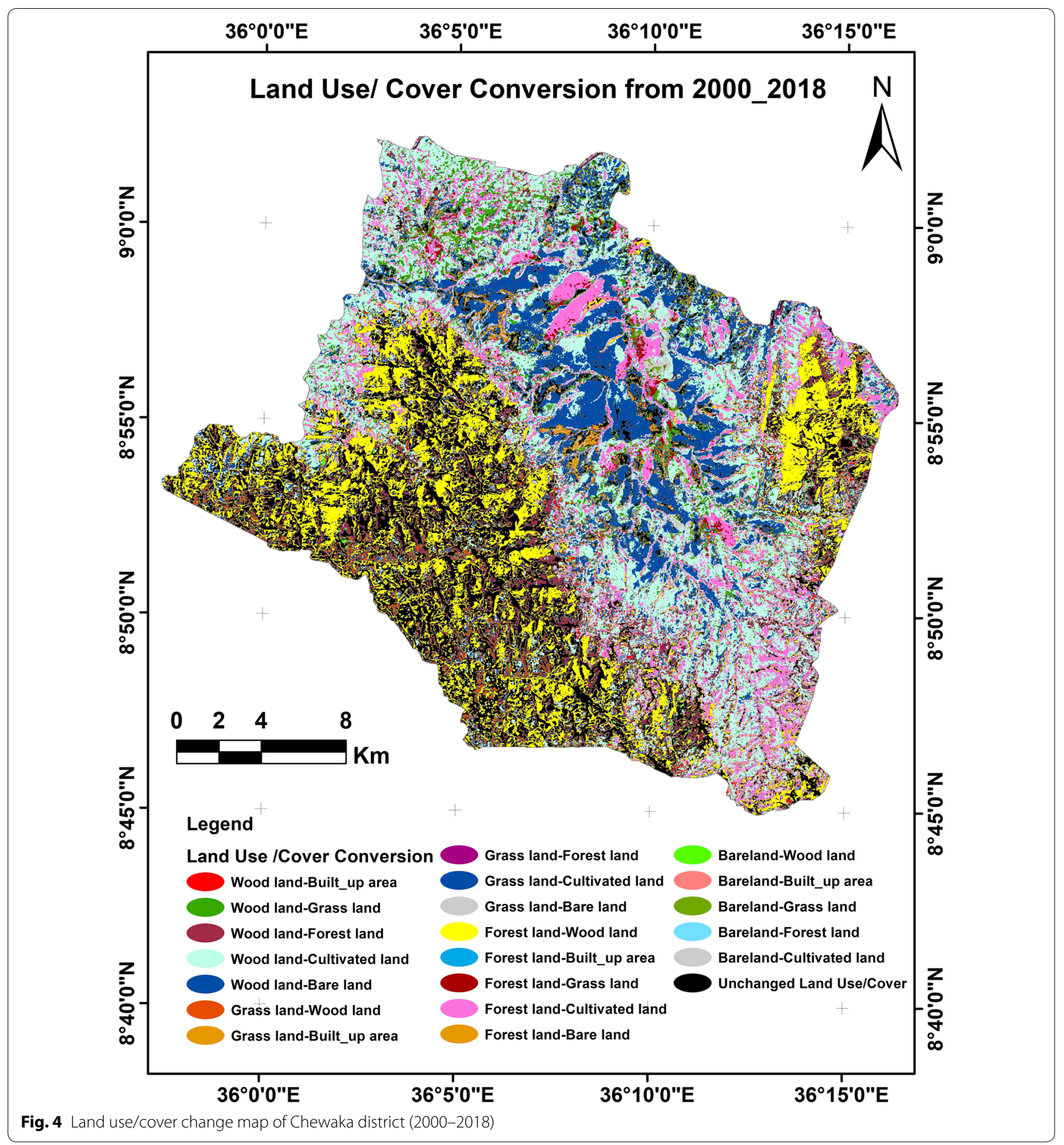

Author details

${ }^{1}$ Department of Geography and Environmental Studies, Mettu University, P.O. Box 318, Mettu, Ethiopia. ${ }^{2}$ Department of Geography and Environmental Studies, Arba Minch University, P.O. Box 21, Arba Minch, Ethiopia.

Published online: 06 March 2020

\section{Reference}

Abera A, Yirgu T, Uncha A (2020) Impact of resettlement scheme on vegetation cover and its implications on conservation in Chewaka district of Ethiopia. Environ Syst Res. https://doi.org/10.1186/s40068-020-00164-7

\section{Publisher's Note}

Springer Nature remains neutral with regard to jurisdictional claims in published maps and institutional affiliations. 